\title{
CIVIL-LAW PROTECTION OF SUBJECTIVE RIGHTS IN THE INFORMATION SPHERE
}

\section{Guyvan Oksana ${ }^{1}$ \\ Sergienko Valeriy ${ }^{2}$}

DOI: http://dx.doi.org/10.30525/978-9934-571-29-9_3

\begin{abstract}
In this article, a study was made of the nature of relations in the sphere of information turnover. Some types of violations of the right to access to information and general features of legal protection of these rights have been clarified. A legal mechanism has been established for mediating the protection of the public and personal information space. Since special laws have been adopted that regulate the implementation of relations in the field of information, they only determine the nature of the unlawful acts, and do not establish sanctions for them, it indicates the lack of information and legal responsibility in the special legal acts as a legal category. Therefore, the perpetrators, as a rule, do not experience prosecution. In this regard, the doctrinal views of scientists on the possibility of the existence of civil liability without sanctions for violations in the form of the so-called obligation to give an account of their actions are examined. It is established that such moral responsibility is not related to protection and legal responsibility and has a regulative rather than a protective nature. The comparative analysis of efficiency and bases of application of measures of civil-law and administrative-legal reaction to offenses in the information sphere is carried out. The legal regulation of information relations in certain regulatory acts that regulate special relations, for example, on consumer protection, in advertising activities, has been studied. Numerous examples of the application of the general types of sanctions provided for in article 16 of the Civil Code for information infringements are presented as ways to protect personal non-property rights.
\end{abstract}

\footnotetext{
${ }^{1}$ Competitor,

Kharkov National University of Internal Affairs, Ukraine

${ }^{2}$ Candidate of Law, Professor,

Head of the Department of Legal Regulation of Economics, Kharkiv National Economic University, Ukraine
} 


\section{Introduction}

At all stages of human development, information was the object of lust. It was believed who owns the information, he owns the world. Indeed, the more information a person has, the greater strategic advantages he achieves in politics, business, and social activities. Therefore, it becomes quite understandable why many states view information as a strategic resource [1, p. 47]. Rapid technological progress in the information sphere puts society, legal science and the legislator in front of the need for effective legal regulation of social relations in this environment.

The issue of ensuring the human right to information is one of the main issues that are ensured and protected by international law. In particular, the freedom to seek, receive and impart information is one of the most important political and personal human rights and is included in the Universal Declaration of Human Rights (article 19). This right is also settled in Art. 10 of the European Convention for the Protection of Human Rights and Fundamental Freedoms. Ukrainian national legislation also pays much attention to this aspect. Article 34 of the Basic Law of Ukraine states that everyone has the right to freely collect, store, use and disseminate information verbally, in writing or in any other way - at his choice. The exercise of these rights may be restricted by law in the interests of national security, territorial integrity or public order in order to prevent disorder or crime, to protect public health, to protect the reputation or rights of others, to prevent the disclosure of information received in confidence, or to ensure the authority and impartiality of justice. Article 32 of the Constitution states that every citizen has the right to get acquainted with state information, local government bodies, institutions and organizations with information about himself that is not a state secret or another secret protected by law.

At the present stage of its development, the society has reached a level where its further progress largely depends on the proper state of information interaction of individual state, public institutions and individuals. Given the significant demand for information, the importance of turnover in this area, the very high relevance of the issue, the significant efforts both of the law-making and law enforcement branches of government, and doctrinal developments require the organization of proper legal support for these relations. This includes the need to formalize legal guarantees for the circulation of information, exchange of information, ways to improve this process, protect the media and the persons who disseminate it and use it. 
Particularly important is the need to establish, at a standard level, the main criteria that ensure the certainty of ownership of specific types of information and its carriers, the legal foundations governing access to it and the possibilities for limiting such access, legal guarantees of free circulation in the information sphere, a clear list of grounds for offenses and - necessarily - sanctions for such violations.

As the information communication in modern society acquires rapid development, especially in the field of public information and electronic communication, including international communication, the normative support lags behind the actual state of affairs, some aspects of legal relations remain insufficiently regulated. In particular, further improvement requires a legal mechanism to protect the public and personal information space. Now this problem has become an important factor not only information, but also general security at the individual, regional and global levels. So, for example, every year in the leading countries of the world not only the number of hacker virus attacks on computer networks is growing rapidly, but also the level of losses incurred to the owners and users of the information resource as a result of such actions by intruders. Therefore, the Ukrainian legal system, as well as international and foreign national practice of law enforcement, requires improvement, first of all, in the implementation and use of adequate means of legal responsibility. This will prevent large-scale negative social consequences, will contribute to the protection of basic human rights for information.

With the development of the information space in society, there is a significant growth of the relevant relations, and then of the offenses in this sphere. Meanwhile, national legislation does not pay enough attention to questions regarding the punishability of such acts. Therefore, we have to state the fact that there is no comprehensive development and implementation of information and legal liability as a legal category in special legal acts, therefore, the perpetrators, as a rule, are not held accountable. At the same time, the sphere of information legal relations, both in terms of their implementation and protection, requires a deep understanding, an adequate choice of methods and means of legal impact, constant adaptation and improvement, taking into account the acquired legal practice. Therefore, the problems of legal responsibility in the information sphere can not remain unnoticed among lawyers, scientists and practitioners. 


\section{Legal basis of responsibility in the information sphere}

The problem of legal responsibility for information offenses is an integral part of the system research of information security issues. The latter relate to the challenges of the humanitarian plan that occur in connection with unauthorized unauthorized access, uncontrolled use and dissemination of personal data, inaccurate information and thus interference in privacy; threats of a political and legal nature to preserve commercial and confidential data. As one of the elements of the general system of punishment for the committed offense, civil liability is intended to ensure the legal order established in the sphere of material civil relations by protecting the violated rights and interests of subjects of information relations with the use of precisely such means, which consist in additional material or organizational encumbrance of the offender. This may be the termination or change of relations, a fair property compensation to the victim as a result of a violation of his information rights.

The institute of civil liability for information infringements is due to the complex nature of the information law, separate norms of which are contained in civil law as a general form (CCU), and in special acts regulating purely information activities, or certain issues of material turnover, which are provided by information exchange in necessary for this volume. In civil literature it has been repeatedly pointed out that responsibility is, although important, but still only an element of negative consequences - sanctions applied to violators of subjective civil law [2, p. 9]. It is this civil-law regulation of the protection of subjective rights differs from criminal and administrative, where the role of sanctions is reduced to the exclusive application of liability measures.

The punishability of unlawful actions in relation to information occurs when an offense is committed. Information infringements are committed in a special plane of human activity - in the sphere of searching, creating, processing, transferring, receiving, storing, protecting and using any information about the surrounding world (information). Often they occur with the use of information tools and information technology, regardless of its form. Information infringement can occur also in other spheres of human activity. Important circumstances for the commission of such acts are the conditions of the information environment for their implementation, related to the use of information, information tools and technologies for working with information regardless of form [3, p. 132]. Civil-law sanctions for vio- 
lations in the information sphere, their type and effectiveness are due to the peculiarities of material relations based on the principles of inadmissibility of arbitrary interference in the sphere of a person's personal life, deprivation of property rights, freedom of information activities, judicial protection of civil rights and interests, etc., and also determined by the direction, seriousness of the violation, the presence of intent and the nature and extent of the damage caused.

As a protective legal institution, legal liability for violations in the information environment should be directed at solving important problems of legal provision of human and social interests in new information dimensions. The main directions of legal regulation should be formed taking into account the public need for implementation and protection of the right to information, protection of ownership of information and information products of intellectual property, protection of personal data, information infrastructures and networks, protection of non-material goods from dissemination of false information. This issue is very urgent, because with the rapid progress of information technology, the level of threats to information circulation is growing daily, so the need for a legal adequate response is obvious.

The right to information is inalienable for the bearer, allows you to freely own, use and dispose of it, that is, it has all the signs of ownership, which to a large extent distinguishes it from other personal non-property rights. In addition, any person has the right to access, that is, to use information as an object of material circulation that is owned or owned by others. These infringements can be directed against these infringements. For example, through unauthorized access, the right to certain types of information, in particular commercial secrets, copyright or patent rights, is violated. One example of illegal behavior in the information sphere is when the information manager denies access to information, wrongfully qualifying it as having access restrictions. Also, the conditions for the dissemination of information can be violated by the user when they are defined in the contract for the provision of information services, to which the parties undertake corresponding obligations, including the use and dissemination of information on the subject matter of the transaction.

The institute of legal responsibility for the commission of offenses in the field of information relations is a legal mechanism that is designed to ensure the effectiveness and effectiveness of law. Today it is extremely necessary for the consistency and stabilization of interactions in the daily life 


\section{Civil-law protection of subjective rights in the information sphere}

of Ukrainian society. Offenses in the information sphere are directed both to the information itself and to the information infrastructure. Therefore, some researchers theoretically substantiate the need to study the appropriate protective mechanisms within the framework of a single concept of an object of encroachment, having formulated it as an "information system" or "information object" - as a set of information contained in databases and information technologies and technical means that ensure its processing [4, p. 88]. Guided by methodological approaches, we can support this thesis. After all, despite the different essential nature of information and the means of its storage, transmission and processing, they as threats can be considered together. This will ensure greater coherence and coherence of normative developments in the field of protecting the information rights of the individual.

In general, the civil-law tools for protecting and protecting the rights of their bearers as a result of offenses in the information sphere, as well as in other areas of protection, is based on private-law principles of interaction of participants in relations based on equality of parties and disposition of constructing the content of relationships. At the same time, guided by the fundamental principles of constructing such relations, the legal doctrine and the relevant legislation go beyond the inadmissibility of arbitrary interference in the sphere of a person's personal life, inadmissibility of depriving the right to property, freedom of contract and business activity, judicial protection of civil rights and interests, and the like. If we ignore the general principle of constructing appropriate mechanisms for regulating relations, both in the regulatory and in the protective and legal context, and focus exclusively on their protective significance, it should be pointed out that civil protection must be exercised in case of violation of the private rights of their bearer. For example, civil liability as an element of negative consequences for the offender in the information sphere comes as a result of causing material or moral harm to individuals or legal entities in violation of the relevant information rights and is the need to compensate for the losses incurred.

In this sense, the sign of civil liability is compensatory and restorative nature, which manifests itself in the application to the guilty person of compulsory measures of a property nature aimed at compensating the inflicted losses to the injured party. But, the sanctions of civil protection of information rights of the individual are not limited only to their compensatory 
component. Legal protection may contain protection and legal requirements provided for by other clauses of Article 16 of the Civil Code or by special regulatory enactments. The choice of the punitive consequences of unlawful acts is often determined not only by the will of the victim, but also by the specifics of the implementation of the information law, the peculiarity of encroachment on him, the significance of negative consequences and the perception of such threat by the rightholder.

Thus, as a matter of fact, most of the normative and legal documents that are used to organize information relations can not be recognized as such that they regulate purely private legal relations, that is, they are in themselves acts of civil legislation. At the same time, considering that the legislator prefers the civil-legal method in regulating the consequences of infringement of the information rights of the individual (although it does not exclude the application of punitive norms of acts of other branches of law), the doctrine is dominated by the idea of the need for the most careful study of the civil aspect of the given problem [5, p. 38]. But, when studying the elements of private relations in essence, including taking into account the predominantly civil law ways of formulating and applying sanctions for their violation, it is necessary to take into account that unlike other material civil rights, in the implementation of information relations, , or not, there is always a certain public interest. In some cases, it can have frank manifestations, more often it is hidden behind other results of the relationship, but one way or another it takes place.

It is the presence of a public element in the structure of the right to information is, a factor that separates the mechanism of legal regulation of information relations from other private law. Therefore, at the current stage of the development of information relations and computer technologies that provide them, we can conclude that the need for special legal measures in this area is the main public interest, first of all. Therefore, legal regulation concerns not only and not so much the interests of persons involved in this area of social relations. The issue of collecting, storing, processing, providing and protecting information causes a social need for their solution. After all, the inability of the state to ensure the effective functioning of the institution of legal responsibility (to timely restore the violated rights of citizens, to compel state bodies and their officials to perform their duties, consistently, regardless of positions, ranks and ranks, apply appropriate measures of state influence to offenders) [6, p. 343]. 


\section{The legal nature of the information rights of the individual}

Actually, information human rights belong to the essence of personal non-property rights. Consequently, for their protection can not be used by far not all the legal means provided by law in the event of violation of real or mandatory rights of participants in legal relations. For example, based on the essence of the right to information, its carrier can not be defended by such means as collecting a contractual penalty, recognizing the right, restoring the situation that existed before the violation, and the like. Nevertheless, most of the legal protection mechanisms that are of a general nature are inherent in the protective sphere in the commented sphere. So, the subject has the right to present a requirement to the manager of information on the provision of information to him, this relationship has a public nature. Under the provisions of article 10 of the special law "On Access to Public Information", everyone has the right to access information about him that is collected and maintained. In turn, information managers possessing information about a person are obliged to provide it unimpeded and free of charge at the request of persons to whom it relates, except in cases provided for by law. If the administrator does not fulfill his obligation to provide public information within a period established by law, a person whose moral rights are violated in this way can present a judicial claim on the defendant's obligation to provide him with the requested information. Putting an appropriate decision by the law enforcement agency will essentially mean that the court has realized the plaintiff's right to defend his right by forcing the debtor to fulfill his duty in kind (Part 5, art. 16 of the Civil Code).

At the same time, the information manager may refuse to grant access to it only in the cases established for this purpose, for example, referring information to such that access to it is restricted. Therefore, in such a case, the question of the legality of such an act must be thoroughly investigated, including in the judicial process. The presence and sufficiency of legal and factual grounds for the recognition of certain information, for example, official, should be checked. And in the absence of such grounds or justifications, denial of access to public information is recognized by the court as illegal. For example, in resolving such a dispute, the Zaporozhye District Administrative Court noted that by refusing to provide a copy of the letter (instruction) on the grounds that this information relates to official information, the respondent failed to comply with the law requirements, since he did not apply the "three-syllable test" and did not I checked whether such a doc- 
ument has information, access to which is not limited. In other words, if the request for obtaining public information contains a requirement to provide a document containing information with limited access (that is, to which the "three-syllable test" applies), the respondent as a subject of power is obliged according to part 7 of article 6 of the Law of Ukraine "On access to public information "to provide information, access to which is not limited, if in general the document containing the requested information can not be provided. However, the respondent did not comply with the requirements of the law, since the hamper completely refused to satisfy the request for public information, arguing that the requested information was official [7].

In spite of the fact that information rights do not have property content, for their legal protection civil-law tools, inherent for protective property relations, in particular for property rights, can be used. This is explained by the fact that, in some cases, information legal relations are of an absolute nature. Therefore, the right of the person who owns the information or that owns the information, as well as the right of the bearer of corporeal law, corresponds to the obligation of an indefinite circle of persons. At the same time, this duty consists in the passive behavior of the obligated subjects. They should not prevent the right holder from exercising his powers at his own discretion, freely choosing the ways of exercising his right: to freely disseminate information, collect it, store it and so on. In view of the foregoing, such ways of protecting information rights, such as prohibiting a third party from taking actions to create obstacles to the exercise of the right, when there is a significant probability of such a violation (preventive protection), eliminate the violations that create such obstacles (like negator protection) look quite acceptable.

According to the legislator's classification, information as an object of civil rights is determined by one of the types of non-material goods (Article 200 of the Civil Code). However, it is not difficult to see that this object has such essential distinctive dimensions, which radically distinguish it from the majority of such objects. In particular, personal intangible goods are therefore called personal, which belong exclusively to the bearer of law, can not be the object of transfer (inalienable). The law does not regulate the order of their creation, change and termination, their specificity to a certain person, as a rule, has a limited period, which is measured by the duration of his life. But almost every measurement of the essence of information as an object of civil law regulation is different from the general manifestations. 
Therefore, information relations, in principle, go beyond the legal regulation provided for by legislation to mediate situations to ensure the implementation and protection of intangible goods. For example, a special legal mechanism should establish the specifics of the definition and procedure for establishing ownership of certain information, including monopoly and other rights for its storage, distribution, protection.

The most significant feature of information that radically distinguishes it from other non-property rights of a person is its multifaceted and comprehensive character. No sphere of human activity, including those that have the appropriate legal support at the present stage, can even be imagined without an information component. In Art. 18 of the Law of Ukraine "On Information" describes the main types of information: statistical, mass, on the activities of state authorities and local self-government bodies, legal, about the individual and the like. As you can see, the list is far from exhaustive, and this is understandable. Therefore, even when all information relations that are currently available are established and subject to legal regulation, rapid changes in real life will cause new information and exchange situations and the need for their resolution. At the same time, taking into account special information activities regimes in order to ensure state and public interests, there is an objective need to introduce special ways of dissemination and use of information.

\section{The state of the legal regulation of the protection of information rights}

In Ukraine, special laws have been adopted that regulate the implementation of relations in the field of information. The new version has the Law of Ukraine "On Information", in May 2011 the Law of Ukraine "On Access to Public Information" came into force, the Law of Ukraine "On Protection of Personal Data" was adopted. With the development of the information space and turnover in society, there is an increase in the scope of legal relations in the information sphere. It is logical that under such conditions, the number of violations of the rights of participants in information circulation and legislation, which mediates information relations, is growing. At the same time, one should agree with the opinion expressed in the literature on the absence of the elaboration of information and legal responsibility as a legal category in special legal acts, therefore, the perpetrators, as a rule, do not experience liability [8]. 
Indeed, special legislation. such as the Law of Ukraine "On Information", the Law of Ukraine "On Protection of Personal Data", the Law of Ukraine "On Access to Public Information", the Law of Ukraine "On Television and Radio Broadcasting", establishes cases when the commission of certain actions is considered unlawful. Let's say, under the instruction of Art. 9 of the Law of Ukraine "On access to public information" and Art. 29 Law "On Information" information managers may classify information as restricted in access only under certain circumstances. The logical construction allows to conclude that in the case when access restrictions occur in the absence of factors determined by law, such actions of the steward are illegal. Under the provisions of Article 24 of the Law of Ukraine "On Access to Public Information", the perpetrators of such violations, as not the provision of a response to a request; Do not provide information on request; unreasonable refusal to satisfy the request for information; not disclosure of information in accordance with Article 15 of the Law; provision or disclosure of inaccurate, inaccurate or incomplete information; untimely provision of information; unreasonable referring of information to information with limited access; failure to register documents; deliberate concealment or destruction of information or documents, are liable for violation of the law on access to public information. But, unfortunately, the content of specific sanctions for these violations remains uncertain.

Now in Ukraine there are many information regulatory legal acts, and their number is constantly growing. But, as the scientists correctly note, quantitative growth does not always ensure a qualitative growth. Therefore, we have such problems with the state of the current legislation as its unsystematic development, internal contradictions in the regulation of various social relations, the unsettledness of many social relations, a disproportion in the correlation between laws and by-laws in favor of the latter, insufficient scientific justification, declarativeness and lack of address of legislative acts, lack of mechanisms for their implementation in these acts [9, p. 42]. These problems are inherent in all branches of law, and not only regulatory regulations governing information relations. But in the latter, such shortcomings are quite significant and indicative because of their intersectoral and comprehensive nature.

Individual researchers in more detail determine the list of problems with regard to the legal regulation of information relations. Among them stand out such as a large number of laws and subordinate regulations in the field of 
information relations. which makes it difficult to find, analyze and agree on them for practical application; absence of a legal, clear, hierarchical system of legislation, which leads to a contradictory interpretation when applying the norms in practice; inconsistency of the conceptual apparatus, incorrectness of certain terms that do not cause appropriate information reflection or do not have a clear definition of their content; terminological inaccuracies, a different interpretation of identical in name and form of concepts and categories, which leads to ambiguous understanding and their application in practice. To the problematic issues in the sphere of the existing legal support of information processes in the society should also be attributed the differences in understanding the structure and composition of the system of legislation and approaches to their formation [10, p. 110].

The legislation of Ukraine on information also includes normative legal acts that mediate relations in individual sectors and are not always of a civil nature, but have an information component that determines the types, forms and means of providing and receiving information that ensures the proper implementation of basic material relationships. In these relations, information exchange is not basic, but auxiliary character, which, however, guarantees the effectiveness and effectiveness of the main legal relations. So, the legal responsibility in the information sphere, which is established by numerous special laws in many spheres of activity, is somehow connected with the turnover of information. For example, in Art. 15 of the Law of Ukraine "On Protection of Consumer Rights" stipulates the consumer's right to information and determines the content of such information. As a sanction for not providing or providing untrue information (about the goods, and about the manufacturer (executor, vendor), the way of using it, about the corresponding risks, etc., which entailed the acquisition of products that do not possess the necessary properties), the consumer is granted the right terminate the contract and demand compensation for losses caused to it. When, as a result of providing inaccurate, incomplete or untimely information about the product and the manufacturer, this caused a threat to the life, health or property of the consumer, the victim has the right to present to the seller (manufacturer, executor) the civil legal requirements provided by law, and also to demand damages, The damage caused to the ego by health, as well as natural objects that are in its possession on the basis of ownership or on other grounds provided for by law or by contract. Compensation in full is subject to losses caused to the consumer by unfair advertising. 
Actually, both national, foreign and international law was blocked by a large set of regulatory material regulating information relations in two separate legal units. The first of them regulates the legal mechanisms for access to and disposition of information. In this sense, we are talking about the legal support for the realization of the subjective right of a person to obtain the possibility of its implementation through the proper performance of a public debt by the information manager. For example, in this way, the result is obtained of obtaining reliable information about the subject due to the proper fulfillment by the distributor of the obligation to verify its reliability (Article 302 of the Civil Code). We are talking about the so-called "positive" freedoms in the sense of realizing the "right to information" by implementing by the obliged person specific positive actions aimed at realizing the subjective right of its bearer. In this way, the right to receive information is realized (Article 302 of the Civil Code); the right to information about their state of health (Article 285 of the Civil Code); the right to reliable information about the state of the environment (Article 293 of the Civil Code); the right of a participant in an economic company to receive information about the activities of the company (Article 116 of the Civil Code); the passenger's right to information about transport and its movement (Article 911 of the Civil Code); the right of a participant in a simple partnership agreement to familiarize himself with all documents on the conduct of common affairs of participants (Article 1136 of the Civil Code); the consumer's right to information about products (Article 4 of the Law of Ukraine "On Protection of Consumer Rights"); the right of the buyer to receive information about the goods (Article 700 of the Civil Code); the right of the customer to receive information from the contractor on the progress of work and (Article 861 of the Civil Code), and others.

Another set of legislative acts is aimed at protecting information, ensuring confidentiality and controllability of certain information. This in the literature is called the process of realizing "non-violent" freedoms, which are the content of the right to preserve and protect information, in particular the protection of its sources and carriers, of certain types of information that have limited access. Such are the rules on confidential information, the right to inviolability of business reputation (Article 94, 299 of the Civil Code); the right to a secret about the state of health (Article 286 of the Civil Code); the right to the secret of donation (Article 290 of the Civil Code); the right to privacy of personal life (Article 301 of the Civil Code); the right to 
confidentiality of correspondence (Article 306 of the Civil Code); property rights of intellectual property for commercial secrets (Article 506 of the Civil Code); the right to bank secrecy (Article 1076 of the Civil Code); the right of the proprietor of production for the non-disclosure of the secrets of production, other confidential information received by the user (Article 1121 of the Civil Code). This approach seems reasonable and rational. It is within these criteria that further law-making in the field under investigation should be developed. This will make it possible to achieve greater coherence and consistency of prescriptions due to the similarity of the regulated relations and their orientation.

\section{The civilized approach to information protection}

It should be noted that among scientists conducting research on this issue, there is still no unanimity regarding the legal nature of the main features of information and information relations as the subject of legal regulation. Attempts to reach a consensus in this regard have been repeated many times, so it is necessary to note their sufficient effectiveness. Scientists have established such characteristic features, which, in general, are inherent in the relations in the commented sphere, as systemic, selective, substantial non-independence, continuity, inexhaustibility, mass character, property to transform, ability to limit, universality, quality, and others. These scientific developments contribute to the allocation of information relations in a certain group identified by the nature of the occurrence, the methods of implementation, the scope of rights and duties and methods of legal protection, which allows for their specific regulation. At the same time, not only the peculiarities of these relations are noted, in fact, which causes certain differences from the general methods of regulation, but also emphasizes the difference in the legal nature of the relationships within the system that can be qualified as information. First, it is proposed to separate purely information relations, which are directly related to the implementation of the powers of the person to receive, distribute. the exchange of information, the exercise of property rights over it, the protection of information resources, etc., and the relations that develop in the implementation of other substantive rights, but for their proper implementation require the involvement of certain information interactions (for example, obtaining information about the goods that are acquired ). These relations should be qualified as those that relate to information. Also, in the legal science it is proposed to meth- 
odologically distinguish between the concepts "information" and "knowledge" [11, p. 41], which is also worthy of attention.

In turn, given that the concept of "information" is very widespread in all respects in society, which are not always of a legal nature, but have an ordinary, personal design, the study of its content has historically been carried out on the basis of philosophical, sociological and cultural concepts on perception of a particular person and society the significance of this phenomenon and the realization of its essence. Expanding the empirical and applied scientific base within the methodologies of natural science disciplines, information was considered as one of the manifestations of the objective motion of matter in space and time. It was in this, in the opinion of the researchers, that the essential attribute value of information was manifested. Consequently, in the scientific and philosophical sense, information is a measure of certainty, organization, order. Difficulties and diversity of matter as phenomena can be perceived and understood by individual actors and society at the same time, thereby achieving certainty and organization in society. Information is associated with another common property of matter - reflection, according to this thesis information can be treated as the content of the reflected process or as an invariant part of the mapping, which can be defined and transferred from one system to another. The practical application of this scientific conclusion is the need to ensure information security in the sphere of social relations by preserving the social interactions of various sociocultural systems [12, p. 40-42].

Information as an object of civil law relations manifests itself in two ways. First, it is a commodity, therefore it is possible to implement information rights and corresponding responsibilities, and consequently, offenses, can be carried out in the field of mandatory legal regulation, including contractual legal instruments. So it is quite an acceptable measure of responsibility to recover penalties for failure to fulfill a certain debt to provide information, if it is provided for in the contract. Also, when the contract for the provision of information services is defective, specified in art. 218-236 CCU (for example, it contradicts the law or moral principles of society, is fictitious, etc.) it can be recognized as invalid. Secondly, information is attributed by law to a variety of personal non-property rights. Consequently, it is of a private nature and is an object of ownership. In such a case, the right to information is absolute and subject to protection using mechanisms inherent in both intangible goods and absolute proprietary rights (property rights). 


\section{Civil liability for violations in the information sphere}

To begin constructing a civil protection and legal mechanism that provides the very foundations of its existence, coordination and coordination of individual components, it is first of all necessary to determine the question of what an information offense is as an illegal act that threatens subjective information rights. In Ukrainian civilization, the formulation of this definition was made by scientists such as Yu.E. Maksimenko and V.A. Lipcane. They postulate information offenses as a socially dangerous, unlawful, guilty act for which tort law in the field of information provides for legal responsibility. Strictly speaking, such an offense is a guilty act of the subject, entailing information and legal responsibility $[13$, p. 251]. Completely agreeing with the postulate that the violation of information rights is an unlawful, guilty (intentional or careless) action or behavior that infringes upon the public relations established by the law arising from the implementation of information activities (receipt, use, dissemination and storage of information) [14, p. 57], we can not yet support the position that civil penalties for such offenses are reduced solely to the application of liability measures.

The variability of the understanding of civil liability is due to the fact that it is an important, but not the only, instrument of civil law that ensures the protection of private legal relations, including information. Therefore, responsibility is traditionally considered in interrelation and correlation with other measures of protection of civil rights [5, p. 38-39]. Protection of the infringed information rights of the person can be carried out by other means with application of sanctions which do not concern responsibility. For example, in the event that the information manager does not provide access to public information as a result of an unlawful decision to restrict access, such a decision may be declared invalid, or if the person refuses to provide information about his personal data processed, such information may be claimed compulsorily. Such protective and legal remedies are provided for in Art. 16 of the Civil Code (part 10 - illegal recognition of decisions, actions or omissions of the authority, or part 5 - enforcement of duties in kind), they are civil protective sanctions, but do not have the status of responsibility, since they do not burden the undue debtor in addition. Actually, the application of such sanctions does not release the latter from the obligation to compensate for harm if it comes to the right holder as a result of the offense, that is, to incur material liability. 
For this reason, we also can not agree with the thesis that the civil liability of acts that are classified as information infringements comes only in accordance with the norms of tort law. It is hardly correct that the position according to which civil liability in the information sphere comes as a result of causing material or moral harm to individuals or legal entities in violation of the relevant norms of information law and is the need to compensate for the losses incurred. Such an approach does not reproduce all the prerequisites and legal consequences with regard to the exclusivity of civil liability as compensatory and recovery results, manifested in the application to the guilty person of compulsory measures of a property nature aimed at compensating the inflicted losses to the injured party.

It is impossible to limit the use of sanctions, including - measures of responsibility, only in cases when, as a result of non-observance of the relevant norms of information law, damage is inflicted on enterprises, institutions, organizations and citizens. Indeed, according to the rules prescribed in the tort norms of Ukrainian laws, in particular, in Ch. $82 \mathrm{CCU}$, art. 22 of the Law of Ukraine "On Protection of Consumer Rights" refers to the need to compensate for harm caused by the wrongful actions of its culprit, including damage due to failure to provide or provide inaccurate or incomplete information. But this way of civil protection is far from exceptional. For example, in Art. $659 \mathrm{CCU}$ provides that a buyer who has not been informed of the rights of third parties to the purchased item has the right to demand a reduction in the price, a consumer who has not received proper information about the goods may demand the termination of the contract (Article 15 of the Law on Protection of Consumer Rights), and in the case when information disseminating information damaging the honor, dignity or business reputation of a citizen is disseminated in the mass media, they must be refuted in the same mass media (Article 37 of the Law of Ukraine "On print media in Ukraine", Art. 277 CCU).

Protective legal relations are not confined to liability alone, but cover other cases related to the protection of law [15, p. 15]. Along with responsibility, there are other consequences unsuitable for the offender, aimed at protecting subjective civil law. In civilization, they are called the means (measures) of the protection of law [16, p. 83-85]. They apply to the offender regardless of his guilt and restore the property position of the person or stop the illegal action. Responsibility is always associated with additional burdens on the offender, and with other ways of protecting the rights of such 
encumbrances there. So, unlike administrative or criminal legal relations, the protection of violated civil rights occurs not only through the application of measures of responsibility. For example, payment of forfeit and compensation of damages does not relieve the obligated person from the performance of the obligation in kind. The actual implementation is aimed at the fulfillment of the action that is stipulated by the content of the obligation, while the responsibility is directed towards fulfilling the additional debt that arose as a result of the offense [17, p. 445]. Responsibility and other types of protection of rights differ among themselves also, guided by the principle of guilt. In particular, responsibility under the general rule comes only for the person's guilty actions, while other civil penalties are applied on the basis of the principle of infliction. Consequently, responsibility is a narrower concept than legal remedies. Civil liability is a type of sanction and is an impact on the offender by depriving him of certain property rights or imposing additional property obligations on him [2, p. 9]. The most striking example of additional burdening as a measure of responsibility is the obligation to compensate for the damage or harm caused. For example, it occurs if, as a result of the publication of unreliable information, the reputation of the business entity has been damaged. The amount of responsibility of the guilty person in such a case is determined by the amount of losses. Means of responsibility are manifested in the consequences of a breach of an existing obligation (contractual liability) or in the consequences of the offense itself, generate a new liability (tort liability). At the same time, measures to protect the subjective law, including legal liability, should be economically justified [18, p. 5].

In the scientific literature the so-called concept of coercion is vividly discussed, according to which coercion is an obligatory manifestation of responsibility. The value of coercion is assessed differently both in the plane of its direct application and for its actual normative consolidation as a legal possibility. Some scholars have criticized the possibility of covering the concept of a voluntary implementation of an overdue debt [19, p. 33]. Others are convinced that the more effective effect is provided by the very possibility of using coercion, because it disciplines the participants in the relationship and creates prerequisites for the voluntary fulfillment of protective obligations, for example, compensation for harm [20, p. 13]. We consider the latter concept to be more balanced and correct.

Taking into account the practical lack of regulations on specific types of information responsibility in the sectoral acts mediating information rela- 
tions, we must be guided by common civil principles. At the same time, it should be borne in mind that the commented sphere of relations in some cases has diversified formations, therefore information responsibility can be realized in the planes of administrative, criminal and disciplinary punishment. Consequently, the concept of information and legal responsibility covers the implementation of legal instruments that are inherent not only in the civil, but also in other branches of law.

Negative legal consequences for a person who violated a certain information legal relationship, differ depending on the method of obtaining and using information. In some cases, information is used by a person for personal consumption, replenishing his knowledge. When such actions are unlawful, the consequence may be an obligation to stop such encroachment. This applies, for example, to unauthorized access to copyright objects, databases, etc. If certain official information (for example, protected by patent law) is illegally used to improve the production process, create new technological developments, in other words, the illegal acquisition and use of such information is carried out with a view to achieving a specific economic result, the emphasis in the application of sanctions should be made on compensatory liability - ii damages and compensation payments.

Civil law also defines special mechanisms for regulating the relationship in terms of coverage and disclosure of information in the media. In case of violation of these rules, the media becomes responsible. It consists in the fact that when a non-pecuniary harm is caused to an individual as a result of dissemination through the mass media of data that do not correspond to reality, those that humiliate the honor and dignity of a citizen, such damage is compensated by a court decision by the appropriate mass media, as well as by high officials and citizens. The amount of compensation for moral damage in monetary terms is determined by the court. At the same time, the duty to prove one's right lies with the defendant - the subject who committed the relevant infringement infringement. Also, the person who disseminated false information must refute them publicly. In addition to refuting inaccurate information and other, provided by Art. $277 \mathrm{CCU}$, ways to protect an individual whose personal non-property rights are violated as a result of the dissemination of unreliable information about him, protection can be exercised by other legal means. For example, in Art. $278 \mathrm{CCU}$ provides for a special protection method, such as the prohibition (termination) of the dissemination of information violating personal non-property rights. 
The need to introduce this method of protection is explained by its considerable effectiveness, including in the preventive plan. It is a normative provision that if a personal non-property right of an individual is violated in a newspaper, book, movie, television program, etc., which are prepared for publication, the court can prohibit their release until it is eliminated, and if they already issued, the court can prohibit (stop) their distribution until the violation is eliminated. If the elimination of the violation is not possible, it is allowed to seize the circulation of newspapers, books, etc. with the aim of destroying it.

At the same time, it is nevertheless necessary to note the decisive role of civil-law protection of the infringed information rights of the individual precisely by compensating for losses or damage that occurred to the victim as a result of the illegal actions of the counterparty. This is the only option for the use of an equivalent compensation mechanism, while the vast majority of infringements on information human rights can be stopped or prevented through the means of responding to other sectoral accessories. At the same time, the presence of harm is a prerequisite for the use of a legal instrument for compensation of the harm caused. The compensation mechanism is aimed at ensuring the most complete reimbursement of the material consequences of the violation of rights at the expense of the person who caused the harm, or other persons on whom, in accordance with the legislation, the duty of compensation for harm is entrusted.

Specificity of compensation liability for information offenses is due to the peculiarities of the object of the offense, the methods of calculation and proof of harm, and the like. In principle, the application of this responsibility is to impose on the offender the obligation to reimburse property or moral damage caused by violation of the norms of the information legislation. At the same time, an important feature of this protective-legal relationship is its universality. This means that a person can resort to it in all cases of violation of subjective civil rights (both in relative and in absolute legal relationships), even though there is no direct mention of this in a special rule of law or in a treaty. In addition, the right holder may, along with compensation for damage caused as a result of the violation, also apply other civil sanctions. So, despite the large number of measures of civil liability as a means of protecting civil rights in the information sphere, compensation for damages plays the role of the leading way of punishing the offender, and the amount of such sanction is calculated in monetary terms. 


\section{Conclusions}

From the study, we can draw certain conclusions. Information relations permeate all spheres of social relations. Being the only resource of interaction, they ensure proper organization of material processes, effective management of them. This greatly complicates the classification of unlawful acts in the information environment, which, in turn, hinders the complex legal provision of information relations, in particular in the sphere of their protection and protection. Taking into account the constant spreading of the spectrum of offenses, it is necessary to develop the concept of an information offense and to fill it with clear content, separating the criminal, administrative, civil, disciplinary responsibility for the object of encroachment, the way and direction of encroachment, the severity of social consequences. It is also necessary to establish as punishable acts aimed at violating other human rights (non-informational character) with the misuse of information, technology or information infrastructure.

The main features of the relevant legislation are the plurality of sources, the dominance of by-laws in the mechanism of legal regulation, the complexity of norms, their instability and the dynamism of acceptance. However, it should be noted significant shortcomings in the formation of an appropriate legal framework. Conceptually they are manifested, first of all, in fluctuations from the need for urgent and special regulation of information relations that are only being formed, to proposals for creating a single codified act that would regulate all existing relations in this sphere. It is impossible to agree with extreme positions, it is necessary, taking into account the complex nature of relations on information turnover, to further develop the relevant legislation in those directions that have historically developed: the implementation of information rights of the individual and the provision of information protection mechanisms. As for the basic, conceptual issues of the development of national legislation in the commented sphere, they should certainly be directed, first of all, to definitive consolidation of fundamental, basic concepts that are intensively used by the legislator in normative legal acts, their use. For example, one should provide legislative unambiguity with such a definition as "secret", "document" and "documented information", "service information", "automated system", "subject of information relations", "information relations system", etc.

Information has its specific characteristics, which reflect its internal nature and essence, influencing the choice of ways to protect information 
rights. Taking into account the peculiarity of information as an object of legal regulation, legal science needs to develop new legal means of response based on an analysis of real threats and risks in the information environment. This will make it possible to eliminate existing gaps in the legislation as soon as possible, since, due to rapid technical progress, unfortunately, the number and level of threats is increasing. As the first and necessary step, the need to harmonize the mechanisms of civil-law protection of information, which are introduced by various acts and continues to have a contradictory character, is seen.

The issue of responsibility for the violation of the information rights of the individual is primarily mediated by the general methods of legal protection prescribed in many acts of Ukrainian legislation. So, such means as termination of an offense, compensation of the caused damage, collecting penalties from the infringer and so on are applied. At the same time, given the extreme prevalence of information relations in all spheres and branches of legal social relations, we can assert that the range of types of sanctions should be broadened at the expense of specific safeguards inherent only in a specific offense. For example, in the case of improper or illegal use of information acquired in a legal way (in fact, if the right is abused), such a way of response as deprivation or restriction of the law may be offered.

Protection of violated subjective rights of a person in the field of information relations in civil law is exercised through the application of sanctions provided for by both article 16 of the Civil Code and other protective norms of liability and proprietary rights. This is especially evident when protecting and protecting such a specific object as information. At the same time, individual protection elements, such as liability, other remedies, have different grounds for application, different meanings and methods of influence. The possibility of ensuring state enforcement, which is carried out by the law enforcement agency, does not in any way eliminate the availability of other means of protection of the violated or contested right. Public interests do not create the need for any case of a civil offense to necessarily apply to bodies with jurisdictional powers. The state can provide an opportunity to exercise the right to the bearer himself, establishing the appropriate framework for appropriate actions, or provides the conditions for the voluntary fulfillment by the debtor of a protective and legal duty. 


\section{References:}

1. Alieva M.F. (2012). Informatsionnaya bezopasnost kak element informatsionnoy kultury [Information security as an element of information culture]. Vestnik Adygeyskiy gosudarsvenny universitet Seria 1: Regionovedenie, philosofia, istoriya, sotsiologiya, yurisprudentsiya, politologiya, kulturologiya no. 4 (108). Pp. 47-52.

2. Krasavchikov O.A. (1973). Otvetstvennost, mery zaschity i sanktsii v sovetskom grazdanskom prave. [Responsibility, protection measures and sanctions in Soviet civil law]. Problemy grazdansko-pravovoy otvetstvennosty i zaschity grazdanskih prav. Sverdlovsk, no. 27. pp. 5-16.

3. Polushkin O.V. (2009) O ponyatii informatsionnogo pravonarusheniya [On the concept of information offense]. Rossiysky yuridicheskiy zurnal. No.3. pp. 207-210.

4. Aristova I.V. (2000). Derzhavna informatsiyna polityka: organizatsiyno-pravovi aspekty: monografia. [State Information Policy: Organizational and Legal Aspects: Monograph] For Collegiate. Ed. O. M. Bandurka. Kharkiv: University of Internal Affairs. 368 p.

5. Tikhomirov O.O. (2015). Tsivilno-pravova vidpovidalnist za informatsiyni pravoporushennya: zagalnoteoretychni aspektu. [Civil liability for information violations: general theoretical aspects] Porivnyalno-analytichne pravo [Electronic scientific and professional edition]. No. 2. pp. 37-40.

6. Bezkluby I., Bobrovnik S., Gritsenko I., etc. (2014) Vidpovidalnist u pravi: philosofia, istoriya, theoriya. Monografiya. [Responsibility in law: philosophy, history, theory: monograph]; per community Ed. I. Bezkluby. Kiev. Gramota, 448 p.

7. Decision of Zaporizhia Regional Administrative Court of April 18, 2016 in case number 808/1093/16 URL: http://www.reyestr.court.gov.ua/Review/57258225.

8. Stadnichenko D.V. Administratyvna vidpovidalnist za informatsiyni pravoporushennya. [Administrative liability for information violations]. URL: http://legalactivity.com.ua/index.php?Itemid=122\&catid=98\%3A20514\&id= 811\%3A260414-13\&lang=en\&option $=$ com_content\&view $=$ article $\quad($ accessed 20 February 2018).

9. Shemshuchenko Yu.S. (1996) Theoretychny zasady kotseptsii rozvytku zakonodavstva Ukrainy. [Theoretical principles of the concept of the development of Ukrainian legislation]. The Concept of the Development of Ukrainian Legislation: Materials of Sciences. Conf., / Institution of Legislation of the Verkhovna Rada of Ukraine. - Kyiv, pp. 42-44.

10. Tsimbalyuk V.S., Gavlovsky V.D., Grishchenko V.V. and others. (2004). Osnovy informatsiynogo prava Ukrainy: Navchalny posibnyk. [Fundamentals of Information Law of Ukraine: Textbook]. Ed. M.Ya. Shvets, R.A. Kalyuzhny and P.V. Melnik. Kyiv: Znannya, 274 p.

11 Bachylo I.L, (2001). Informatsionnoe pravo: Uchebnik. [Information Law: Textbook] I.L. Bachilo, V.N. Lopatin, M.A. Fedotov, Ed. B.N. Topornik. St. Petersburg: Legal Center Press, 789 p.

12. Khitarova I.Yu. (2008). Duhovnaya zhizn obschestva kak obekt informatsionnoy bezopasnosti. [Spiritual life of society as an object of information security]. Etnosotsium i meznatsionalnaya kultura. No. 6. pp. 37-47. 
13. Lipkan V.A., Maksimenko Yu.E. (2013). Zasady rozvitku informatsiynoyi deliktologiyi. [Principles of Development of Information Delictology]. Pravo Ukrainy. No. 10. pp. 249-256.

14. Pisarenko G. M. (2016). Yuridychna vidpovidalnist v informatsiyniy sferi: okremi aspekty stanovlennya. [Legal responsibility in the information sphere: separate aspects of formation]. Naukovy visnyk Uzgorodskogo natsionalnogo universitetu. Seria "Pravo". V. 2, pp. 55-58.

15. Orlova E.A, Nosov V.A. (1983). Ohranitelnye grazhdansko-pravovye normy i pravootnosheniya. [Protective civil law norms and legal relations]. Proceedings of the Materialno-pravovye i protsesualnye problemy zaschity subektivnyh prav. Interuniversity thematic collection. Yaroslavl. Yaroslav. state. university. Pp. 10-18.

16. Tsivilne pravo Ukrainy: Akademichny kurs. Pidruchnyk. [Civil Law of Ukraine:Academic Course. Textbook]. In 2 volumes / per eng. Ed. Y.M. ShevchenkoV. 1. General part. Kyiv: Publishing House "In Yure", 2003. 520 p.

17. Kharitonov Ye.O., Startsev O.V. (2007). Tsivilne pravo Ukrainy: Pidruchnyk. [Civil Law of Ukraine: Textbook]. Issue 2, reb. and listens. Kyiv: Istina. 816 p.

18. Butnev V.V. (1990). Yuridicheskaya otvetstvennost i pravovoe gosudarstvo. [Legal responsibility and the lawful state] Proceedings of the Legal responsibility: general problems and branch features. Far Eastern State University. Abstracts of the inter-university conference of young jurists. Vladivostok: FENU, pp. 4-5.

19. Bratus' S.N. (1973). Spornye voprosy theorii yuridicheskoy otvetstvennosti [Controversial issues of the theory of legal responsibility]. Sovetskoe gosudarstvo i pravo. No. 4. pp. 27-35.

20. Tarkhov V.A. (1973). Otvetstvennost po sovetskomu grazhdanskomu pravu. [Responsibility for Soviet civil law]. Saratov: The Saratov University Publishing House, 1973. 456. 